\title{
The megalithic tombs in the region of Belas (Sintra, Portugal) and their aesthetic manifestations
}

\author{
Las tumbas megalíticas en la región de Belas (Sintra, Portugal) y sus manifestaciones \\ estéticas
}

João Luís Cardoso (*)

Rui Boaventura (**)

\begin{abstract}
Within the region of Lisbon, artistic manifestations from megalithic tombs are virtually unknown, although they are frequent in other regions. The megalithic group of Belas has a particular relevance to this subject given its two types of aesthetic and artistic features already published by previous authors, but not properly emphasized or characterized. On one hand, the builders of the three known tombs -Pedra dos Mouros, Monte Abraão and Estria- made selective usage of certain types of rock slabs, based on their morphological characteristics on the slab surfaces, structuring them within an intentional aesthetic pattern. On the other hand, on the external surface of one of the slabs of Pedra dos Mouros, two engraved anthropomorphic figurines are known, but need to be reevaluated taking into account the most recent studies.
\end{abstract}

\section{RESUMEN}

En la región de Lisboa, las manifestaciones artísticas en tumbas megaliticas son virtualmente desconocidas, aunque son frecuentes en otras regiones. El conjunto megalitico de Belas tiene una relevancia especial a este respecto. Está representado por dos tipos de rasgos estéticos, ya publicados por otros autores pero no destacados o caracterizados con propiedad. Por un lado, los constructores de las tres tumbas conocidas-Pedra dos Mouros, Monte Abraão y Estria-seleccionaron ciertos

(*) Open University (Universidade Aberta); Coordinator of the Centre for Archaeological Studies of the County of Oeiras (Municipality of Oeiras). Avd. Jacques Delors, 211. 2740-122 Porto Salvo. Portugal. Correo e.: arqueolo@univ-ab.pt

(**) Center for Archaeology of the University of Lisbon (UNIARQ); Archaeologist with the Municipality of Odivelas. Alameda da Universidade. 1600-214 Lisboa. Portugal. Correo e.: boaventura.rui@gmail.com

Recibido: 9-XII-2010; aceptado: 12-III-2011. tipos de losas de piedra a partir de las características morfológicas de sus superficies, estructurándolas de acuerdo con un patrón estético intencional. Por otro, se conocen dos figuritas antropomorfas grabadas sobre la superficie externa de una de las losas de Pedra dos Mouros que requieren volver a ser evaluadas considerando los estudios más recientes.

Key words: Iberian Peninsula; Megalithism; Neolithic; Chalcolithic; Rock Art; Archaeology of Death and Burial; Historiography; Geoarchaeology.

Palabras clave: Península Ibérica; Megalitismo; Neolítico; Calcolítico; Arte rupestre; Arqueología de la muerte; Historiografía; Geoarqueología.

\section{INTRODUCTION}

One possible explanation for the almost total lack of artistic manifestations known in megalithic tombs of Estremadura might be the very rarity in the region of this type of structure, also known as anta or dolmen. Indeed, this becomes evident when we analyze the distribution of the various types of tomb used during the $4^{\text {th }}$ and $3^{\text {rd }}$ millennia BC. Only twenty or so dolmens are known in the region (Fig. 1), of which several no longer exist, having been destroyed during the $20^{\text {th }}$ century (Boaventura 2009). However, this may not be the main reason for the apparent absence of art features, as a similar lack of artwork is notable amongst monuments of the same type in the Northern Alentejo (of which there are hundreds), when compared with other regions of the central interior and north of Portugal. It may of course merely reflect a lack of investment in 


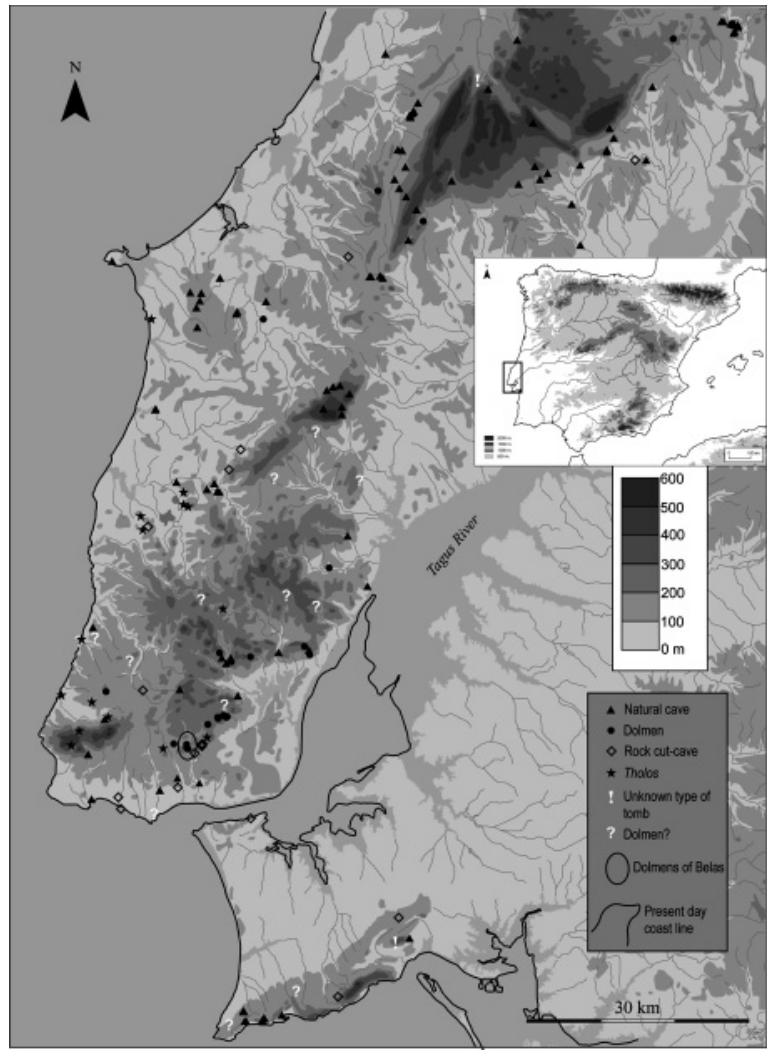

Fig. 1. The Belas megalithic group in the context of various types of prehistoric tombs in Estremadura (Portugal). Map produced by Maia Langley (Boaventura 2009).

identifying such manifestations; the various examples in the region of Cáceres would have remained unknown if it were not for the painstaking work of Primitiva Bueno, Rodrigo de Balbín and collaborators (Bueno and Balbín 1992, 2003; Bueno et al. 2007, 2009a). However, in some cases, the issue was given consideration in the past, as attested by José Leite Vasconcelos' curious reference to what was not found in the dolmen of Arruda, namely "cupmarks, nor any kind of engraving or painting"(1).

In the dolmens that have survived until today in the region of Lisbon, attempts have been made to check for the existence of paintings, engravings and other pertinent features. This has mostly been unsuccessful, with the exception of the

(1) Vasconcelos, J. L. 1898: Relatório da exploração da anta do 'Casal das Antas de Baixo' (Arruda) [Manuscript]. J. L. de Vasconcelos Archive. Box 6 (A-B): Notes by provenience. Available at Library of Museu Nacional de Arqueologia. Lisbon.
Belas megalithic cluster, which consists of the dolmens of Pedra dos Mouros, Monte Abraão and Estria, classified as National Monuments by Decree 16/6/1910, published in the Government's official gazette (Diário do Governo No. 136 of 23 June 1910). These are located across a fairly vast Cretaceous platform (Fig. 2), formed by deposits from the Lower and Middle Albian-Cenomanian, with limestones and marls from the "Belasian" (Ramalho et al. 1993; Almeida 1991), topped by hard deposits from the Upper Cenomanian. In altitude, they are around 200-210 m, sloping slightly towards the southeast. The southern side of the platform is covered with a layer of basalt, interrupted in the extreme north by trachyte veins (Ribeiro 1880: 5-6; Ramalho et al. 1993; Almeida 1991). According to Carlos Ribeiro, these intrusions would have contributed to the local alteration of the limestone, which was taken advantage of in the construction of the dolmens of Pedra dos Mouros and Estria (Ribeiro 1880: passim).

The dolmens of Belas were identified during the first geological surveys of the Lisbon outskirts led by C. Ribeiro in the middle of the $19^{\text {th }}$ century, and were subsequently explored and published by him (Ribeiro 1880). A host of legends had grown up around these monuments, but unfortunately, few people remember them today and they persist only in printed texts. The construction of a chapel nearby dedicated to Nosso Senhor da Serra ("Our Lord of the Moun-

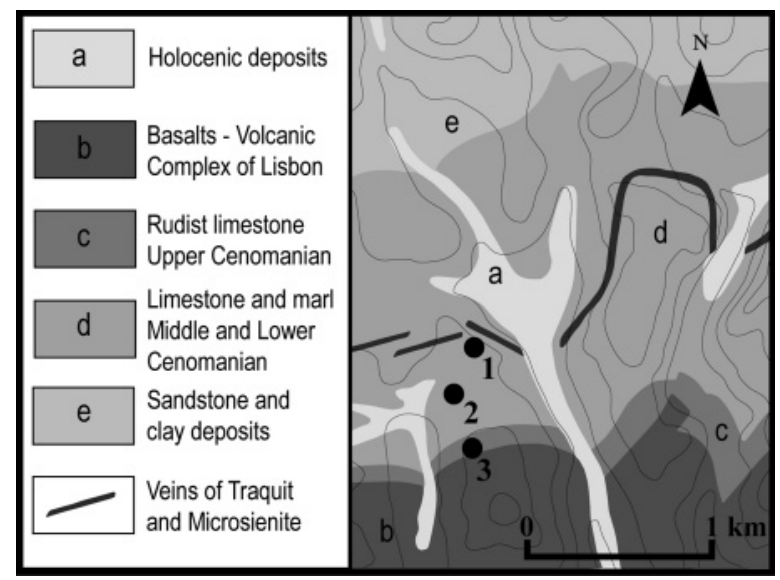

Fig. 2. The geology of Belas area and the megalithic tombs: 1. Pedra dos Mouros; 2. Estria; 3. Monte Abraão (Portugal). Adapted from Almeida (1991). 
tain") may also reflect an intention to Christianize the platform of the ancient cluster of tombs (Casa et al. 1998). Indeed, the annual pilgrimage to the chapel would include a climbing and descent of the highest slab of Pedra dos Mouros; women would apparently slide down the slab to ensure their fertility (Ferreira 1963), a practice that has long been recorded (Correia 1917) and is documented in photographs from around 1900/1910 (Benoliel 1907; Casa et al. 1998), although in those, only men can be seen atop the largest slab of the tomb that was still preserved (Fig. 3A).

Around the 1860s Ignacio Vilhena Barbosa described Pedra dos Mouros in the following terms, not referring to any funerary connotation: "On top of the hills bordering the flat plain of the estate on its western side loom two enormous rocks that are unusual not only in shape but also in the way they are arranged. They are two large pointed slabs, placed perpendicular to each other so as to form an angle, joined at the base up to a third of their height. From there upwards the rocks separate because of their pyramid shape. Only their base is on the ground, and so much is on the surface that they seem to have been put there by human hands. There are no other rocks quite like this in the area. Is this a natural curiosity or could it be some construction dating from before the monarchy, which was never completed or of which only these vestiges remain? According to popular tradition they were built by the Moors and used as a lookout post" (Barbosa 1863: 185 free translation).

Associated to this description, the picture (Barbosa 1863: 192) entitled Penedos na quinta de Bellas (Crags in Bellas estate), emphasizes their large size compared to a person (Fig. 3B). However, this author never considered this structure to be a dolmen, reserving that name for the 'dolmen' of Adrenunes, the only one he knew of in Estremadura (Barbosa 1868). Ironically, that is in fact a natural pile of granite boulders.

\section{CHARACTERIZATION OF THE MONUMENTS}

\subsection{Pedra dos Mouros}

The dolmen of Pedra dos Mouros (Código Nacional de Sítio ("Site National Code"): CNS-
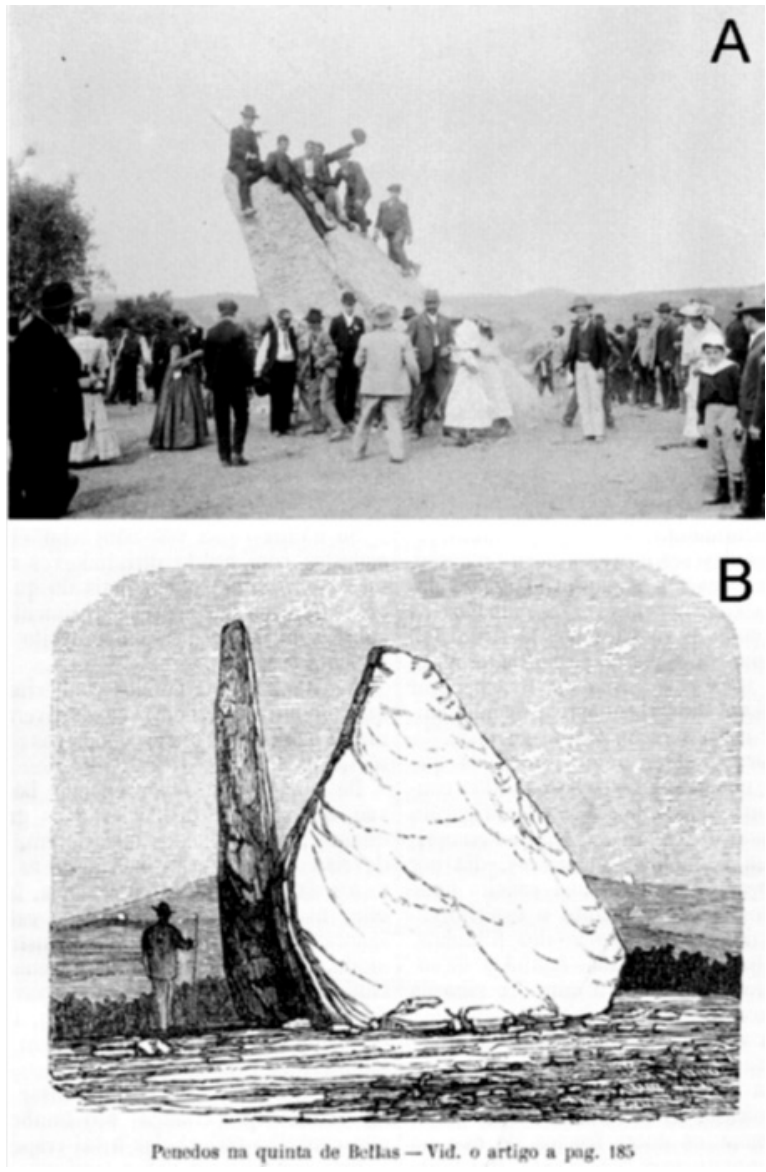

Fig. 3A. Pilgrims of Our Lord of the Mountain Chapel (Capela do Nosso Senhor da Serra) at the dolmen of Pedra dos Mouros, Belas (Portugal), in 1907. Photo by J. Benoliel (Municipality of Lisbon Photographic Archive). B. Illustration of Pedra dos Mouros (Barbosa 1863).

11301) or Pedra Alta (Benoliel 1907) was explored in 1876 by C. Ribeiro, who published the results soon after (Ribeiro 1880). The monument is still today located within the grounds of the estate of Belas, today known as Senhor da Serra ("Lord of the Mountain"), $400 \mathrm{~m}$ west of the chapel itself. It is within sight of the dolmen of Monte Abraão, some $800 \mathrm{~m}$ to the south, but not of the dolmen of Estria, which is only $400 \mathrm{~m}$ south-southwest, but in a depression of the terrain. C. Ribeiro described Pedra dos Mouros as "an incomplete monument" with only three orthostats remaining in situ. At that time, slab 'A' was tilting northwards and was circa $5 \mathrm{~m}$ long (length above ground), 3,7 $\mathrm{m}$ wide and $0,27 \mathrm{~m}$ thick (on average). It was partially supported by slab 'B', 
which was then still whole, and which was $4,5 \mathrm{~m}$ long, $2 \mathrm{~m}$ wide and 0,25 $\mathrm{m}$ thick (on average). Slab 'B', for its part, was leaning on slab 'C', which was around $4 \mathrm{~m}$ wide, but rose only $1 \mathrm{~m}$ above the ground, as it was broken, though no fragment could be seen in the vicinity. During excavation, four smaller slabs were also found, which C. Ribeiro thought may have corresponded to fragments of other larger ones, or possibly, "to the table or capstone that crowned the monument, if there was one" (Ribeiro 1880: 6 - free translation). In his plan, he showed two of those features at the eastern side.

The three slabs clearly identified as such were of "very hard grey clayish limestone", similar in all respects to the substratum in the immediate vicinity (Ribeiro 1880: 6), a claim that has since been confirmed. The German couple Leisner also turned their attention to the monument, but no detailed plan showing the four small slabs mentioned above has been located in their archives. However, in the published ground plan (Leisner 1965: taf. 53: 1), at least two of them are represented and they are similar in all respects to those indicated by $\mathrm{C}$. Ribeiro. In the set of drawings and pictures of this dolmen, it is possible to see that those features on the eastern side were almost vertical, and probably functioned as wedges. Some photographs were probably obtained on the $13^{\text {th }}$ of April 1933 (date when the drawing was done), when slab 'B' was still whole (Fig. 4A) (Leisner 1965: taf. 143: 3). This slab must, therefore, have broken between that date and the $5^{\text {th }}$ of December 1943, when another photograph by the German couple recorded the altered situation(2) that remained until recently (Fig. 4B). In 2004, the parts described were still there. Slab ' $B$ ' had broken into three (the base still in situ, with a larger segment and a smaller fragment, which seemed to have been in the process of breaking off in the early photographs) and there were two other parts, attributed to wedges, on the eastern side, now lying horizontally due to the toppling of slab 'A'.

C. Ribeiro thought that the chamber headstone was on the southern side, formed by slabs ' $A$ ' and ' $\mathrm{B}$ ' (Ribeiro 1880: 6). While this interpretation is understandable, given the scarcity of systematic data then available, other conclusions that later

(2) Photo in folder Leis64. Leisner Archive, Instituto de Gestão do Património Arquitectónico e Arqueológico, Lisbon. authors presented are more surprising. V. Leisner (1965: 70 and taf. 53: 1) considered that slab ' $A$ ' (called slab $\mathrm{C}$ in her plan) was the roof slab, while O. da Veiga Ferreira (1959: 216) suggested that the corridor was located to the northeast, though emphasizing that further excavation was needed to confirm this. In fact, this author did plan an excavation in the area with V. Leisner(3), although it was not carried out due to illness of the later.

In the light of previous suggestions, the subsequent accumulation and systematization of data concerning this type of megalithic tomb have led us to believe that slab ' $\mathrm{C}$ ' corresponds to the headstone. This hypothesis is based on the overlapping of slab ' $\mathrm{B}$ ' and ' $\mathrm{A}$ ' in sequence (a pattern that occurs in other tombs) and also on the width of slab ' $\mathrm{C}$ '. Thus, it is likely that this dolmen had a large polygonal chamber, around $4 \mathrm{~m}$ wide by $4 \mathrm{~m}$ long, which was open towards the raising sun, though for now, it is not possible to guarantee the presence of a corridor (Fig. 4C). It was probably oriented to the east, which would make the layout of the other parts of the structure more plausible. However, this needs to be confirmed through the excavation of the northeast-southeast quadrants of that tomb, areas that were not covered in the original intervention, according to the account given by C. Ribeiro (1880: 4-6).

As for the chronological-cultural context of this monument, the remains (which are limited, due to earlier looting) suggest that it was first used in the last centuries of the $4^{\text {th }}$ millennium $\mathrm{BC}$, and that this usage intensified in the first half of the $3^{\text {rd }}$ millennium $\mathrm{BC}$ given the presence of various votive objects in limestone (Boaventura 2009). The apparent absence of geometric microliths, ground stone tools and bell beaker ceramic should be pointed out.

The debate as to the architecture of the monument and the position that the remaining slabs occupied within it is important for this work. In fact, the interior surfaces of the slab ' $\mathrm{C}$ ' attributed to the headstone and the second lateral slab, 'A', are totally covered with ichnofossils, resulting from the tubular filling of the tracks left by invertebrates (Fig. 4C). Only slab 'B' does not have that characteristic. This apparent organization is more obvious in the other two dolmens, as we shall see below.

(3) Leisner, V. 1961: [Letter] 1961 Maio 19 [to] O. V. Ferreira (hadwrited). In J. L. Cardoso (2008: 748). 

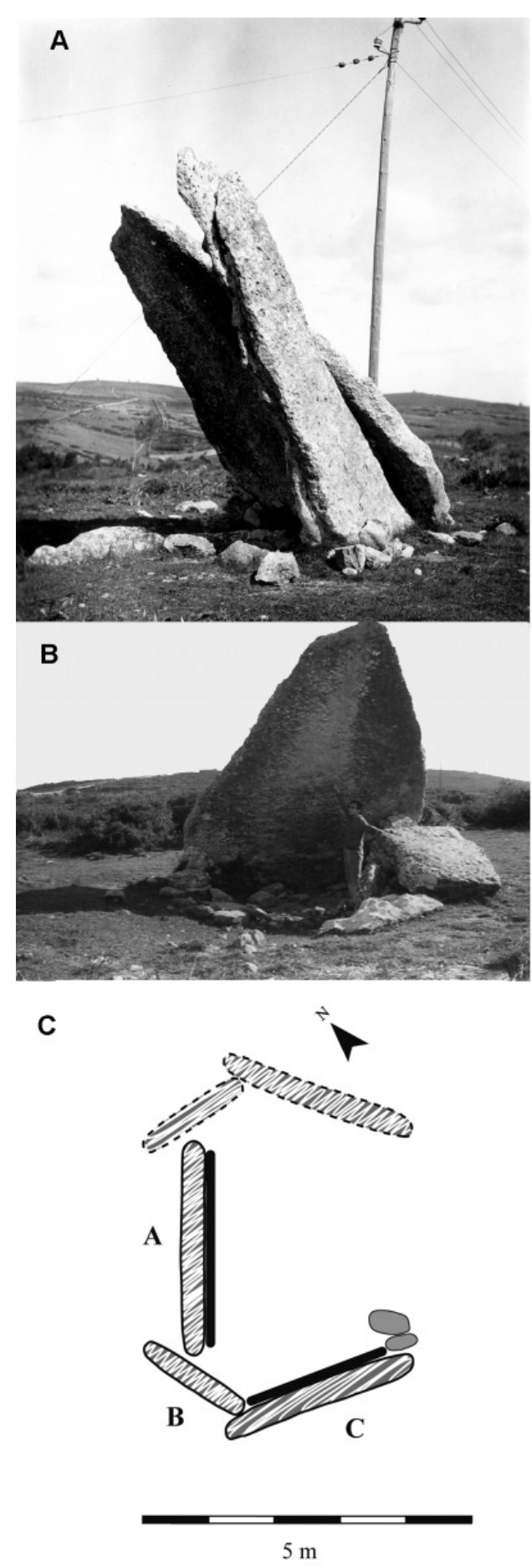

Fig. 4A. Dolmen of Pedra dos Mouros (Belas, Portugal) in 1933 with slabs 'B' and 'C' still complete. Photo by G. and V. Leisner 1933 (Leisner Archive, Instituto de Gestão do Património Arquitectónico e Arqueológico, Lisbon). B. In 1970 with slab 'B' broken (photo: J. L. Cardoso). C. Its plan adapted from V. Leisner (1965), showing (black line) the surfaces of the slabs with ichnofossils.
Another notable iconographic feature concerns the two figures on the outer surface of the largest slab, 1,37 $\mathrm{m}$ above ground. Both are anthropomorphic, though one is more stylized (cruciform) and the other more explicit, with arms, hands and legs; and both have a maximum length of $0,17 \mathrm{~m}$ (Fig. 5). These aspects were pointed out long after the original exploration by V. Correia (1917), who considers them to be prehistoric, representing female and male figurines respectively. One of the reasons given to justify this antiquity is the patina in the furrows of the engraving, which causes the author to wonder if they were executed before the slab was covered by the mound - or if indeed a mound had ever existed. During a visit in 2004, it was found that these engravings were now very faint and that

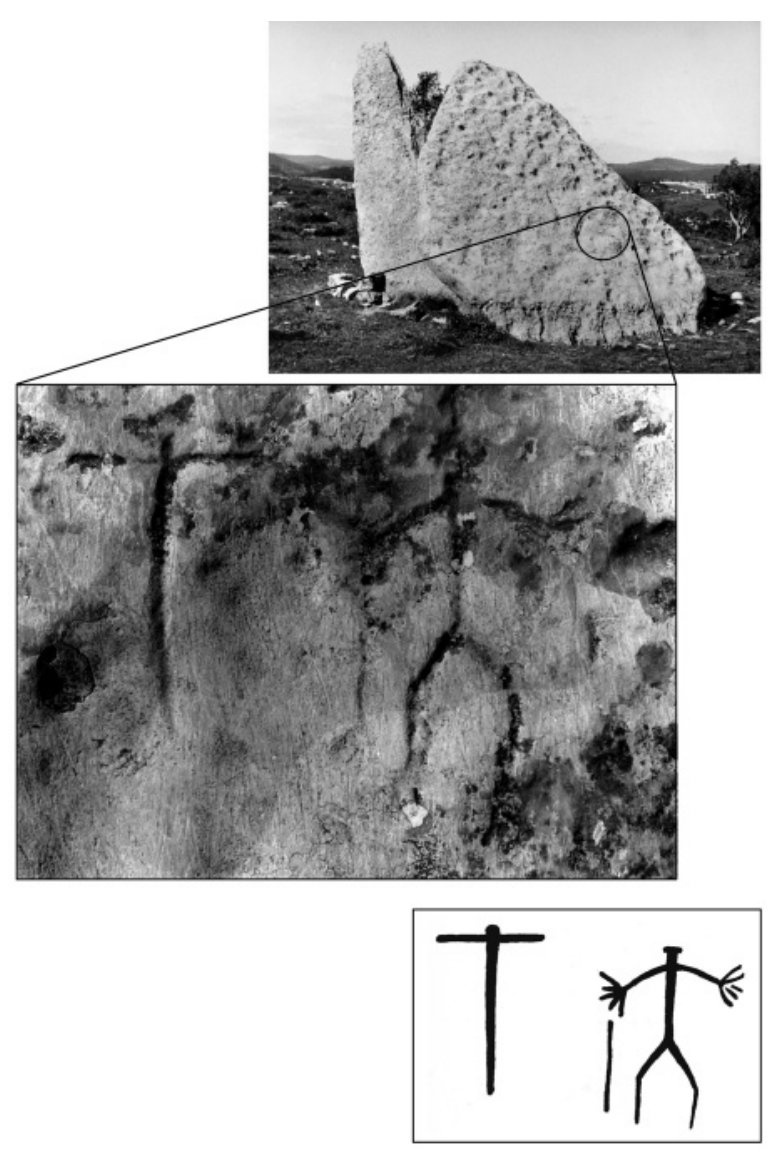

Fig. 5. Engravings on slab ' $\mathrm{C}$ ' at the dolmen of Pedra dos Mouros (Belas, Portugal). Photos by G. and V. Leisner 1933 (Leisner Archive, Instituto de Gestão do Património Arquitectónico e Arqueológico, Lisbon) and drawing by V. Correia (1917). 
they had been superimposed by more recent graffiti and paintings.

\subsection{Monte Abraão}

The dolmen of Monte Abraão (CNS-655), also known as Pedra do Monte Abraão (Ribeiro 1880) or Alto de Monte Abraão (Simões 1878)(4), was detected by C. Ribeiro, but only excavated years later. Judging by the labels glued to some objects from this site deposited at the Geologic Museum, it took place between February 1875 and September 1878 . The sifting of the earth possibly was conducted in that last year, as loose teeth are the pieces that bear this date, with the mention 'sifted earth' (Boaventura 2009).

The designation of the dolmen, "Abrahams hill", seems to reveal an attempt by the local population to explain that structure, or the group of the three tomb structures, particularly given its location on the upper part of the platform. In fact, at an altitude of $213 \mathrm{~m}$, this is the most elevated of the three tombs. From there, the dolmen of Pedra dos Mouros can be seen, some $800 \mathrm{~m}$ to the north, although the dolmen of Estria is not visible from the site, despite being only $300 \mathrm{~m}$ to the north-northwest.

According to C. Ribeiro (1880: 9), Monte Abraão was the best-preserved of all "the megaliths (...) in the neighbourhood of Bellas", and was oriented in a west-east direction, presenting a different style of Pedra dos Mouros, which, according to the geologist, pointed northwards. The tomb was set on an deposit of hard limestone from the Upper Cenomanian (Ribeiro 1880: 5-6; Almeida 1991; Ramalho et al. 1993), and was partially covered with a layer of 'blood-red' clay, at some points as much as $0,60 \mathrm{~m}$ thick, resulting from the erosion of the basalt upland to the south.

The construction of the monument was preceded by the excavation of the space needed, including the sockets for the orthostats. The author suggested that fire may have been used to break down some parts of the geologic bedrock. The slabs used were probably obtained a few hundred metres away to the north from the under-

(4) Also registered in a tag glued to the artifact number MG178.242. Geologic Museum, Laboratório Nacional de Energia e Geologia, Lisbon. lying deposit, which yielded regular-shaped blocks, although with very rough surfaces.

The tomb has a chamber formed by at least 6 orthostats 'A'-'F', the largest of which corresponds to the headstone, on which still leans (though only partially) the roof slab (Figs. 6A and $6 \mathrm{~B})$. The main slab was reinforced on its inner face by an upright slab and a stone ring on the outer side, which would surrounded the other orthostats. C. Ribeiro also indicated the existence of three slabs ('H', 'I' and 'J') aligned in the southern side of the corridor, apparently still in situ (Ribeiro 1880: 9-11; Leisner 1965: taf. 54). He also mentioned that, on the northern side, in addition to a small upright slab, ' $\mathrm{K}$ ' ( $G$ in Ribeiro $1880)$, there was a line of stones oriented to the east, sometimes vertical, for an extension of 3 to $4 \mathrm{~m}$, probably supports for slabs since disappeared. The remaining extension of the corridor was presumed by the finds and by a concentration of quartzite, basalt and limestone pebbles amongst which bone remains were also found. However, these pebbles also seem to have appeared throughout the whole area of the dolmen, particularly in the surface layer, perhaps related to the mound of the tomb, now gone.

Before 2009, until the excavation led by João Albergaria of the archaeological company Terra Levis, the existence of most of the items described by C. Ribeiro had been verified, although they were found to be more deteriorated and broken. Block ' $\mathrm{H}$ ' was no longer visible, slab ' $\mathrm{B}$ ' was broken and had fallen inside the chamber and the capstone ' $G$ ' had a longitudinal fracture that can soon cause its collapse. However, the depression formed by the corridor and chamber were still visible, partially filled with gravel, placed there during the safekeeping work carried out in 1986 (Marques and Ferreira 1987; Marques et al. 1991). Indeed, the masonry pillar that was built at that time to support the capstone managed to delay the imminent collapse.

By comparing the information provided by C. Ribeiro and by G. and V. Leisner, we can get an idea of the general dimensions of the structure (Fig. 6B): The chamber would have been $2,80 \mathrm{~m}$

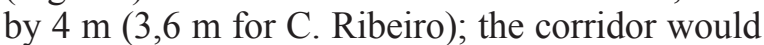
have extended for $8 \mathrm{~m}$, with an average width of $2 \mathrm{~m}$, according to Ribeiro (1880), although the stone parts were detected only in the first $4 \mathrm{~m}$; the capstone was about $4,4 \mathrm{~m}$ by $3,2 \mathrm{~m}$. The headstone would have stood around $3 \mathrm{~m}$ above ground, 


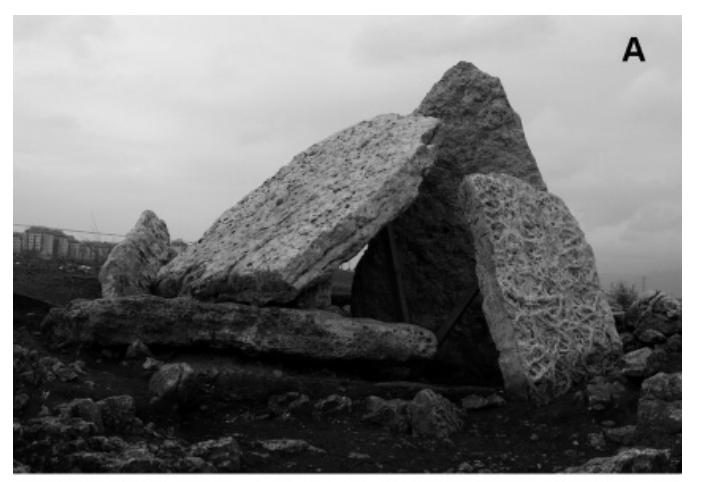

$$
\text { N }
$$

A
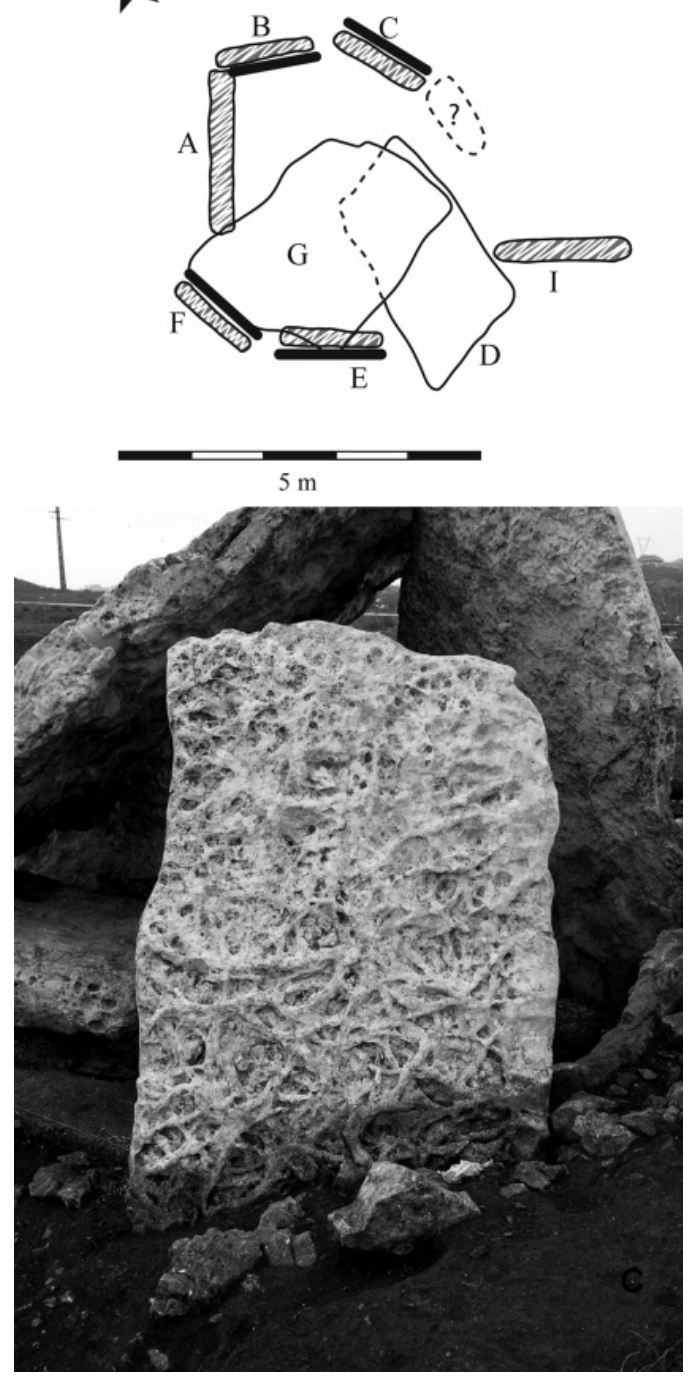

Fig. 6A. Dolmen of Monte Abraão (Belas, Portugal) in 2009 (photo: R. Boaventura). B. Its plan adapted from V. Leisner (1965) showing (black line) the surfaces of the slabs with ichnofossils. C. Slab 'C' (photo: R. Boaventura). prior to excavation ( $4 \mathrm{~m}$ in total) and was $2,10 \mathrm{~m}$ wide, while the others were smaller, as they were broken; their approximate widths were: ' $\mathrm{B}$ ' and ' $F$ ' - $1 \mathrm{~m}$; ' $\mathrm{C}$ ' - 1,30 m; 'E' - 1,40 m; 'D' - 1,50 $\mathrm{m}$. The exception is slab ' $\mathrm{D}$ ', which is apparently whole but has toppled over; this is around 3,50 m long, closer to the size of the headstone.

As in the case of Pedra dos Mouros, C. Ribeiro does not appear to have fully understood the structure of Monte Abraão. He interpreted slab ' $G$ ' not as the capstone of the tomb but as only one of the slabs deliberately inclined and held up by slab ' $\mathrm{D}$ ', believing that the tomb had not been designed to receive a roof, which would have distinguished it from other tombs in the region (Ribeiro 1880: 12). This misunderstanding may be explained by the lack of information available about this type of tomb at the time.

In the light of the information above, it is possible to conclude that this dolmen had a polygonal chamber consisting of 6 slabs, with probably a seventh one on the northern side (Fig. 6B). East of the chamber there may have been a corridor, at least $4 \mathrm{~m}$ long, formed by orthostats, followed by an antechamber, marked by the aforementioned concentration of pebbles. However, the 2 $\mathrm{m}$ width of the passage should be taken with reservations, because it was calculated on the basis of the distribution of findings in the area, rather than by the distance between the slabs or possible sockets. In fact, it seems more likely that the distance between slabs 'H'-'I' and the small slab ' $\mathrm{K}$ ' corresponds to the width of the primitive corridor, which would have been around 1,20 m (the recent mentioned re-excavation may be able to clarify this). The existence of a tumulus has not been proved, and it is only possible to guarantee the existence of a stone ring around the outside, adjoining the slabs.

Although the chamber is incomplete, the headstone ' $A$ ' is preserved made of rough limestone but without ichnofossils. It is flanked by two slabs ('B' and ' $F$ '), whose ichnofossil-covered surfaces are facing inwards into the interior of the monument. The next slabs (' $C$ ' and ' $E$ '), for their part, have fossils on the surfaces that are turned outwards (Figs. 6B and 6C). Of the pair of slabs that probably followed, it is only possible to verify that the surfaces of slab ' $D$ ', on the southern side, do not have this type of features, although observation of the inner surface is restricted by the fact that the slab has 
fallen onto the ground. Although a slab on the northern side is missing, the symmetrical arrangement of surfaces bearing such strange markings around the axis of the monument would have created a particular effect that was clearly intentional, revealing a deliberately aesthetic, if not magical-religious concern.

As for the chronological-cultural context of this monument, the archaeological remains collected, though limited due to earlier disturbances, suggest that it was initially used in the last centuries of the $4^{\text {th }}$ millennium $\mathrm{BC}$, and that this usage intensified in the first half of the $3^{\text {rd }}$ millennium BC. They include various votive objects in limestone, idol-plaques, beaker ceramics and bifacial flaked stone artifacts, such as an halberd, a dagger and arrowheads (Boaventura 2009). The presence of bell beakers, as well as some objects of adornment, such as bone buttons, would also suggest an use around the mid- $3^{\text {rd }}$ millennium BC.

\subsection{Estria}

The dolmen of Estria (CNS-3001), also known as Cova da Estria (Simões 1878)(5) or Istria (Ferreira 1959: 215) is the third tomb of the Belas group, and like the others, was first identified by C. Ribeiro. According to a short note of C. Ribeiro referring to this tomb, written in the only field notebook that has been located(6) at the Historical Archive of the National Laboratory for Energy and Geology (LNEG), the archaeological excavation took place between January and February of 1875 . On the $26^{\text {th }}$ of January, C. Ribeiro placed this "dolmen nearby Estrias' farmhouse, $200 \mathrm{~m}$ west of the wall demarcating the Marquis of Bellas Estate. The tomb was located in a depression relieve or on a slope towards a depression that was south of Idanha hamlet"; he also refers to the site as Cova da Estria meaning "Estria's hole". The date mentioned is not far in time from another that appears on a tag glued to a human long bone - " $8 / 2 /[18] 75$ From the estate of Mr. Abreu, cova da Estria"(7).

(5) Also referred by C. Ribeiro 1871-1875: [Field notebook] 22-VI to 10-VIII-1871 [until] Jan. e Fev. 1875. [Without inventory number]. Available at the National Laboratory for Energy and Geology Historical Archive.

(6) Vide note 5.

(7) Human bone number MG719.40. Deposited at Geological Museum. National Laboratory for Energy and Geology, Lisbon.
At the end of the $20^{\text {th }}$ century, safe keeping work was carried out on this dolmen by the then Portuguese Institute for the Cultural Heritage (Instituto Português do Património Cultural), revealing that widespread violation had taken place in the area of the chamber, near the headstone, although the general structure of the monument remained much as it had been described by C. Ribeiro (Marques and Ferreira 1987; Marques et al. 1991). Later, in 1995, when the planned construction of a motorway and service station looked set to destroy the dolmen, the tomb was re-excavated and restored by sequent institution, then designated by "Portuguese Institute for Architectural and Archaeological Heritage" (Instituto Português do Património Arquitectónico e Arqueológico), led by the archaeologist Ana Carvalho Dias. Unfortunately, no report was made of this excavation, and attempts to contact the archaeologist since 2004 were frustrated making difficult to clarify the criteria that presided over the structural reconstruction of the tomb's passage.

C. Ribeiro (1880: 62) had thought it strange that the tomb appeared to be "hidden in a fold or pleat of land, leaving only the tops of some of the stones visible at ground level in the act of discovery". Indeed, the very name estria reflects the idea of a fold or furrow on the surface (Fig. 7A). According to the geologist, the location was chosen so that the builders could take advantage of a narrow strip of limestone that had been altered as a result of intrusion from the "porphyroid" vein, also found near to Pedra dos Mouros. Thus, the construction was arranged inside that strip of bedrock, which was oriented in east-northeast/west-southwest direction and was around 2 to $5 \mathrm{~m}$ in width. This situation explains why it is not possible to see the other two tombs of the Belas megalithic group from there, although they are quite close by (400 $\mathrm{m}$ to Pedra dos Mouros towards the northeast, and $300 \mathrm{~m}$ to Monte Abraão towards the southeast).

According to C. Ribeiro, the dolmen consisted of a space with a chamber and a corridor (Fig. 7B), similar to Monte Abraão, although dug more deeply into the bedrock. In the chamber he mentioned "nine slabs raised upright", which left only a narrow gully for access to the corridor. Despite the geologist refer his description to a plan, on this drawing, only seven slabs and two small blocks (which of course makes a total of nine) are in fact visible. However, he does men- 

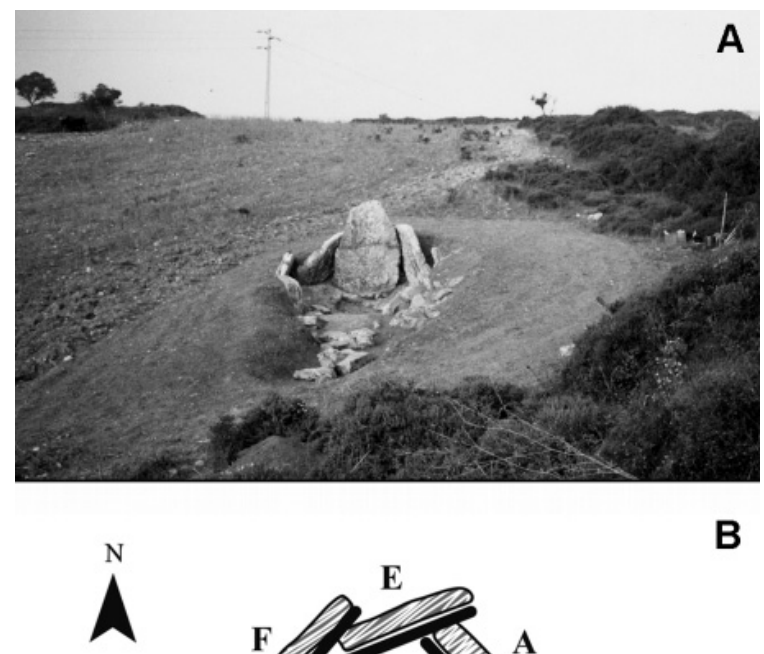

B
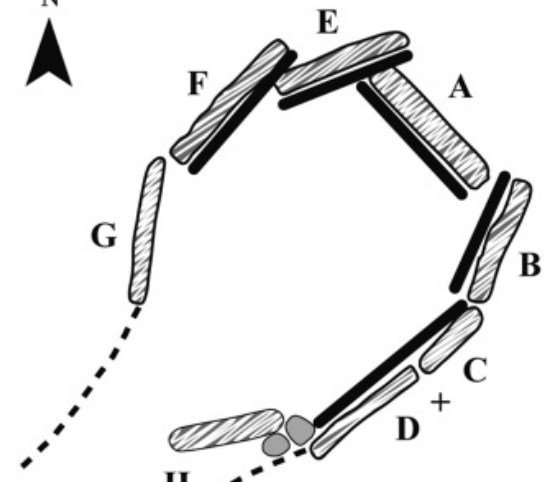

D
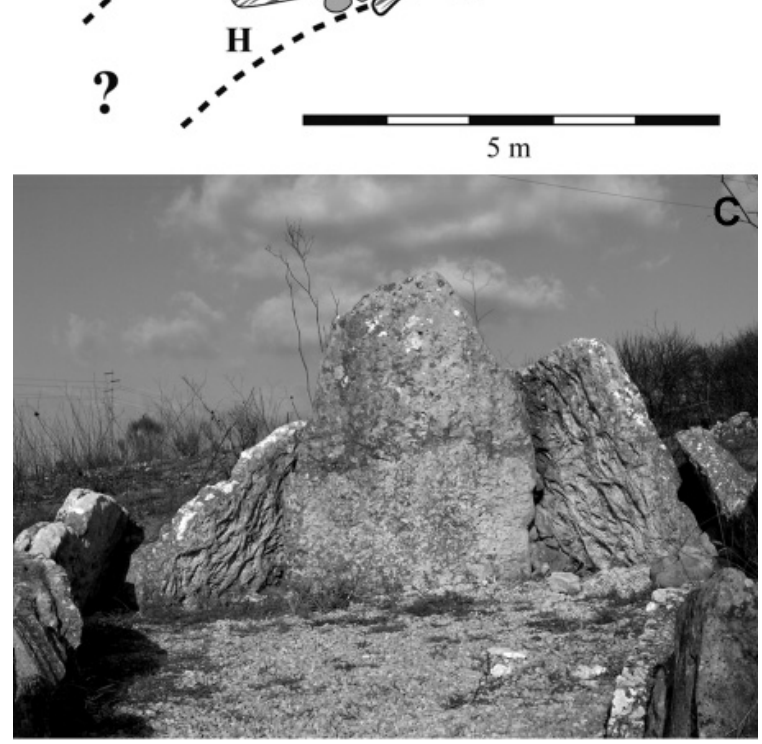

Fig. 7A. Dolmen of Estria (Belas, Portugal), after cleaning in 1987 (photo: Teresa Marques). B. Its plan adapted from V. Leisner (1965) showing (black line) the surfaces of the slabs with ichnofossils. C. Details of the slabs (photo in 2008: R. Boaventura).

tion further on that "the enclosure or chamber was completed by other smaller slabs dug deeply into the ground" (Ribeiro 1880: 63). Analy- zing the elevation presented in perspective (Ribeiro 1880: fig. 65), the seven slabs can be seen alongside other blocks from the probable narrowing of the chamber to the corridor. The corridor was delimited "by two rows of small limestone slabs dug deeply into the ground and parallel to each other", and was around $10 \mathrm{~m}$ in length, although this part of the structure is not represented in the plan (Ribeiro 1880: 63-64), or even in the rough version of his notes (8). The fact that the corridor area is not represented may be due to the chaotic appearance of the blocks, though it may also reflect the fact that work on that stretch was carried out by an inexperienced worker and was not properly recorded. Finally, although C. Ribeiro had detected some large fragments of blocks, he found none that seemed to belong to the capstone.

All the slabs from the dolmen were, according to the geologist, of hard grey limestone, extracted from local deposits. Workers from the region called them bancos reaes ("exquisite embankments") as they yielded large slabs "able to resist great loads, and endure the destructive action of the weather, such as those used in bridges and other rustic works that required safety, durability and economy" (Ribeiro 1880: 63). Also, they were of the same type as used in the dolmens of Pedra dos Mouros and Monte Abraão.

In the chamber of the tomb of Estria (Fig. 7B), it can be seen the typical overlapping of most of the slabs starting by leaning on the headstone ' $A$ '. The outer surface of this slab is rough and pitted, while the other, turned inwards into the chamber, has ichnofossils. It is flanked by two others (' $\mathrm{B}$ ' and ' $E$ '), which also have surfaces with ichnofossils facing the interior of the chamber. The next slabs ('C-D' and ' $E$ '), which have the same characteristics, were also arranged with the trace fossil surfaces turned inwards (Slabs ' $C$ ' and ' $D$ ' previously formed a single block, arranged in a peculiar way to better withstand the earth pressure from the adjacent slope, and were supported by ' $B$ ' and ' $H$ '). Finally, the limestone slabs ' $G$ ' and ' $\mathrm{H}$ ', which have a more clay-based component, are relatively smooth and devoid of ichnofossils. As in Monte Abraão, the symmetrical arrangement of surfaces completely covered with entwined tubular shapes (Fig. 7C) would have had an aesthetic or even magical-religious pur-

(8) Vide nota 5. 
pose, given the obvious deliberateness about their positioning in the group.

Both C. Ribeiro (1880: 63) and V. Leisner (1965: taf. 57) failed to record slab ' $H$ ', which may be explained by its small remaining height in the ground. As it seems to have been broken before the others by the date of excavation, it may denounce that those works did not have reached the bedrock in the whole area of the enclosure. On the other hand, the images obtained by G. and V. Leisner during their 1944 visit(9) show that the interior of the tomb was quite full of rubble. This might also explain their interpretation, which was limited to a survey of the visible elevation to the north-northeast. In fact, slab ' $\mathrm{H}$ ' was only identified during the cleaning and safe keeping work carried out in 1986.

The chamber of the dolmen, with a headstone ('A') around 2,75 $\mathrm{m}$ in height (above the ground) and $1,9 \mathrm{~m}$ width at the base, would have been approximately $4 \mathrm{~m}$ long and 3,80 $\mathrm{m}$ wide (maximum), and would have extended into the corridor, according to C. Ribeiro (1880: 62), by "some 10 metres". This extension has today been recreated without knowing in fact if any sockets or other remains had been found to substantiate this reconstruction. Despite doubts as to the characteristics and extension of the corridor, the tomb clearly had a polygonal chamber with seven slabs, as suggested by V. Leisner (1965) and a passage. Thus, the hypothesis suggested by $\mathrm{O}$. V. Ferreira (1959) that this tomb was a "covered gallery" does not make a strong case.

C. Ribeiro noted the abnormal layout to the west, attributing it to the morphology of the surrounding land; for otherwise, the enclosure would have been quickly filled and covered over by sediments. In fact, the readings taken indicate an orientation of $213^{\circ}$ or $212^{\circ}$ (Hoskin 2001; measurement by Cândido Marciano da Silva). Consequently, the structure was largely buried in the slope and no information is available about the existence of a possible mound, although some blocks can be glimpsed in the presently visible structure which could be a stone ring of an outer buttress.

Evidence collected at this anta, such as the absolute dating suggest that it was first used in the transition from the $4^{\text {th }}$ to the $3^{\text {rd }}$ millennia $\mathrm{BC}$, or only in the first half of the $3^{\text {rd }}$ millennium $\mathrm{BC}$.

(9) Photos in folder Leis64. Leisner Archive, Instituto de Gestão do Património Arquitectónico e Arqueológico, Lisbon.
During this period, it appears to have been more intensely used, judging by the presence of limestone artifacts, a slate idol-crosier, and concavebased arrowheads (Boaventura 2009). This seems to indicate that it was built and used later than the other two dolmens in the group, which might explain the different layout of this tomb in relation to the canonical patterns followed by dolmens in the Lisbon region and also identified generally in other regions (Hoskin 2001; Gonçalves 1999). The greater modernity of this tomb could also explain the different layout of the slabs with ichnofossils, for, as described above, the surfaces bearing fossil tracks seem to be more systematically arranged to face inwards, highlighting the aesthetic and magical-religious effect produced by them.

The apparent absence of bell beakers might mean that the tomb fell into disuse before the middle of the $3^{\text {rd }}$ millennium $\mathrm{BC}$, when these artifacts started to be frequent.

\section{DISCUSSION}

Given the features described above, it seems appropriate to talk of a necropolises area defined and constituted by, for what we know today, the three dolmens of Belas. The various tombs were apparently used simultaneously for a period of at least 300 years during the first quarter of the $3^{\text {rd }}$ millennium BC. Some of the particular characteristics of the architecture and their respective remains, as well as the radiocarbon dating obtained from some of the individuals deposited inside, suggest that the dolmens of Pedra dos Mouros and Monte Abraão probably preceded Estria. However, only a more expanded program of radiocarbon dating could confirm this with more certainty.

Some of the slabs used in the dolmens of Belas have surfaces completely covered with ichnofossils. These were obtained from limestone deposits dated to the Lower and Middle Cenomanian, either locally (in the case of Pedra dos Mouros and Estria) or a few hundred meters away (in the case of Monte Abraão).

Although the tombs are no longer complete, the arrangement of the slabs is worthy of note. From what is possible to judge today, the headstone of Pedra dos Mouros had this feature, but the next one to it on the southern side did not,

Trab. Prehist., 68, N. ${ }^{\circ}$ 2, julio-diciembre 2011, pp. 297-312, ISSN: 0082-5638

doi: $10.3989 /$ tp.2011.11071 
though the next to the right of it did. The dolmen of Estria apparently offers the most complete case. Here the headstone and the successive two pairs of slabs all have their inner surfaces covered with ichnofossils. Only the last pair of slabs is of smooth orthostats with a more clayish component. Finally, the chamber of Monte Abraão has a peculiar layout: the headstone is quite rough, like the roof slab, but without ichnofossils, and is flanked by two orthostats whose inner surface is covered by those fossil tracks; these are followed by two other slabs, one each side, with those fossil surfaces facing outwards. Of the following pair only the southern slab is now evident, with no ichnofossils on its surfaces. This alternation would surely have created an intense scenic effect inside the tomb, particularly in the glimmer of the torchlight, when the entwined patterns on the slabs would have given the impression that the surfaces were moving. However, the fact that some of the ichnofossil surfaces are turned outwards suggests that the stone structure of the anta may not have been completely covered by a mound.

Thus, there appears to have been intentionality, not only as regards the selection of slabs that had one of their surfaces completely covered with tubular ichnofossils, but also in the way that these were architecturally arranged in the three monuments.

Despite this observation should be highlighted, it is not the first time it was partially noted. In fact, Luís de Albuquerque e Castro (1961) had already called attention to the intentional use of slabs with ichnofossils, although remained forgotten, and has only recently been remembered (Bueno et al. 2009b). At the time it was an innovative study, not only because of its content but also because of the period when it was produced, when observations of this nature (particularly when they concerned elements that were not man-made) tended to be belittled by researchers and considered to be groundless.

Although this author did not systematize his observations, as the present work is conducting, he did give importance to the fact that orthostats were selected for their "rough" surfaces, when others with more regular surfaces could easily have been obtained from the same sites. For L. A. Castro, it was the dolmen of Monte Abraão which displayed this most clearly; for, despite being located on a bed of hard limestones, which could have supplied slabs of the appropriate dimensions, these were passed over in favor of the Lower and Middle Cenomanian limestone deposits, a few hundred meters away towards north from the tomb. From these they took only those stones with abundant ichnofossils, as seen in all three of these monuments, though particularly in Estria, as we have seen.

Thus, the author concluded that, although these were naturally-occurring objects (the decorative effect was produced by the tracks of invertebrates), these deposits were intentionally used because the slabs produced an aesthetic effect appreciated by the builders of the tombs in question.

It would be useful to know whether the situation identified at the Belas group of three dolmens has any equivalent in similar monuments that are apparently devoid of any 'classical' artistic manifestations such as paintings or engravings. In the first case, the blocks used did not show any signs of work. This option reminds us of Chris Scarre's suggestion (Scarre 2004) that there is intentionality in choice, and above all, in the valorization of raw materials. In Estremadura, there seems to be another case of the aesthetic exploitation of natural blocks in the dolmen of Carcavelos, whose headstone is formed of conchiferous limestone, not so evident in the other slabs (Boaventura 2009). A similar case, in the neighbouring region of the Alentejo, is the dolmen of Rabuje 4, Monforte, which also seems to manifest aesthetic intentionality. Here, the chamber is formed of a biotite schist headstone, flanked by two pairs of orthostats of red granite, extending the corridor with more schist slabs (Boaventura 1999-2000, 2000). Intentionality can also be seen in the selection of the stone slabs used in the four megalithic tombs of Vale de Rodrigo (Évora). Some of the slabs seem to have been transported from a distance of around $8 \mathrm{~km}$, which suggests that the type of stone was significant for the builders of the tombs. In fact, none used stone of local origin, although the substratum consisted of gneisses. Naturally, the predominant stone types are found more locally, such as biotitic tonalites (around 1 to $2 \mathrm{kms}$ away), but there was clearly a demand for other rocks, such as porphyroid granodiorites (available 6-8 kms away), probably because of the effect produced by the feldspar phenocrystals. However, the layout of the corresponding slabs in the monuments has not re- 
vealed any patterned organization (Kalb 1996). It was also concluded that the bigger the tomb, the greater the diversity of stones used (Kalb and Höck 1995).

Another question concerns the existence of two engraved figures on the outer surface of one of the slabs at Pedra dos Mouros, mentioned above. These representations were not mentioned by C. Ribeiro, and it was V. Correia that referred to it (Correia 1917), attributing them to the prehistoric period. In fact, both may be included into the stylistic sequence defined by J. Cabré one year before (Cabré 1916), from representations of a naturalistic character to those that are exclusively schematic, such as these. H. Breuil (1933) was of the same opinion, including them in the group of Iberian dolmen carvings then known. Around that time, other similar engravings were identified in prehistoric open-air rock sanctuaries of the same type in the Minho region - as in the case of Gião, Arcos de Valdevez (Fontes 1932) -and in the Upper Alentejo- with Pedra da Talisca and Penha das Gamelas, Mora (Correia 1921). These involve panels engraved onto large granite boulders, as observed in another sanctuary, also identified in the same region, namely Penedo de Almoinha, Mora (Zbyszewski et al. 1977). The panels are dominated by cruciform shapes of varying degrees of complexity, with parallels in the simple cross found at Pedra do Mouros, which may have been made at different periods, both prehistoric and more recently.

The anthropomorphic shape, with its exaggerated hands, including the five fingers on each one, is more interesting ichnographically, although the parallels that can be invoked also cover a broad time span. In Portugal, the oldest example of a similar motif, attributed to the Chalcolithic ( $1^{\text {st }}$ half of the $3^{\text {rd }}$ millennium BC) and also produced by engraving, was identified on the inner surface of a slab belonging to the dolmen of Afife, Viana do Castelo, region of Minho (Silva 1993). This is possibly a schematic anthropomorphic figure with legs, shoulders and arms along the body, finishing with hands with fingers, superimposed continuously upon another simpler anthropomorphic representation. Also from the Chalcolithic period are anthropomorphic figures with hands depicted on sandstone or (more rarely) slate and schist plaques, which occur mostly in dolmens of the Northwest Alentejo, extending into the south of Beira Baixa - although ex- amples are known both to the west, as is the case of the fragment of a plaque from the dolmen of Penedo Gordo, Gavião, and megalithic tombs from the province of Cáceres, Spain (Cunha and Cardoso 2002-2003). Indeed, one of the most suggestive examples is from a brownish schist plaque collected at the cave of Lapa do Bugio (Sesimbra, in the region of Lisbon), which depicts, in the central tablet, an Almerian idol with long filiform arms ending in hands, with fingers represented by short carved lines (Cardoso 1992).

In the Bronze Age, there are many steles bearing representations of arms and hands, particularly in the Cáceres/Salamanca regions (Spain). The oldest of these may date from the end of the Chalcolithic/Early Bronze Age, continuing until the Final Bronze or even the beginning of the Iron Age (Almagro-Gorbea 1993), with the most modern known as "warrior steles" extremeñas. In this last case, there are some examples on Portuguese territory: the stele of Ervidel II, Beja (Gomes and Monteiro 1976-1977), which shows a standing warrior, facing left, whose arms, bent into a right angle, end in large hands with five fingers. The stele of Figueira, Vila do Bispo, also bears the image of a warrior with his arms raised, ending in hands with fingers (Almagro Basch 1966: Lám. XVII). Finally the phallic stele of Monte de S. Martinho, Castelo Branco (Almagro Basch 1966: Lám. III) shows a standing person holding a bow aimed at a deer; once more his fingers are exaggeratedly represented as in the previous examples. Also, from Portuguese territory, there was an engraving of a male anthropomorphic in a sandstone panel at Magoito beach (Sintra), now lost - this representation was closer associated to several geometric depictions, some with solar appearance, attributed to Iron Age (Sousa 1990). However, despite being geographically the closest example to Pedra dos Mouros, its morphology is different: has a phallic depiction within a massive rectangular contour body, circular head with nose and eyes and feet with fingers, features that do not occur at the dolmen of Belas.

The examples above seem to be enough to illustrate the remarkable longevity of human representations with exaggerated hands, extending from the Late Neolithic to the Final Bronze age/ beginning of the Iron Age. Indeed, there are even more modern examples, including from other 
geographic areas, such as Valcamonica, Italy (Anati 1980: 61).

One could not finish comments about the most significant depictions of engraved anthropomorphs with hands in Portuguese territory without referring the group of Penedo do Matrimónio (Matrimony boulder), located at Montalegre, Vila Real. These engravings, one male and another female, with big hands and feet with fingers, were attribute to regional Late Chalcolithic, given the presence of putative daggers, which typology was considered of that period (Bettencourt et al. 2004). Also, according to the authors, the boulder where they are located was later sacralized by the engraving of a cruciform, just four meters away. However, M. V. Gomes (2004-2005) based on the published drawings of those engravings, considered that the typology of the daggers associated with the anthropomorphic depictions is related to the Iron Age culture of the Northwest of Iberian Peninsula from the $\mathrm{III}^{\mathrm{rd}} / \mathrm{II}^{\text {nd }}$ centuries BC. And, if so, then this would correspond to cults of the end of Iron Age, associated with Lugus and Nabia deities (Gomes 2004-2005). Still according to that author, this remarkable group has other parallels, such as the engravings of Laxe dos Homes (Pontevedera), already mentioned as a "divine couple" (Anati 1980), represented by a pair of anthropomorphic female and male figurines, the later presenting a helmet with horns. The recent discovery of several engraved panels along the mountains of Pampilhosa da Serra deserves to be mentioned as well: the panel of Bregada has a depiction of a male anthropomorphic figurine very similar to the one from Laxe dos Homes, with wide open and high up hands, feet oversized with big fingers and what it looks to be a helmet with horns (Batata and Gaspar 2009).

In some of the examples given above, the arms of the figurines appear elevated up, in a probable connection with the cosmos, highlighted by open hands. These hands could have been receivers/transmitters of the energy itself and of the symbolic charge of these representations. Such examples can be associated to Levantine rock art from the rock-shelters V and VII of Pla de Petracos (Beltrán 1989), or 'prayers' representations in ceramic pots with cardinal decoration of Early Neolithic, as those from Cueva de l'Or, Valencia (Martí Oliver and Hernández Pérez 1988).
Nevertheless, in other cases the arms are pending, such in anthropomorphic depictions of the Chalcolithic slate or sandstone plaques and the steles group of Hurdes/Gata, despite a few examples from Extremadura present the arms up. The fact that the depiction from Pedra dos Mouros has the arms open horizontally and the legs flexed does makes it more difficult to attribute a more precise chronological period.

In light of this, although there are no reliable criteria for the inclusion of anthropomorphic representations of Pedra dos Mouros into the period when the monument was built, there are also no arguments to the contrary. Thus, it would seem prudent to suggest a chronology between the construction of the monument and the Iron Age.

\section{CONCLUSIONS}

This study has led to the following general conclusions:

1. The reassessment of the funeral architecture from the three dolmens of Belas -Pedra dos Mouros, Monte Abraão and Estria- has allowed us to confirm the existence in all three megaliths of slabs with surfaces that are covered with ichnofossils. These have produced whimsical shapes through the filling of tracks and galleries formed by the movement of invertebrates through former sea beds, presently conserved in the marly limestone stratification surfaces of the Lower and Middle Cenomanian that exist in the region.

2. These building materials were intentionally sought out. For although, in the case of Pedra dos Mouros and Estria, they could have been directly obtained from outcrops in the vicinity, at Monte Abraão, despite the fact that the geological substratum at the site of the monument consists of coral limestone deposits from the Upper Cenomanian that would have been perfectly suitable as a building material, these were passed over in favor of deposits with ichnofossils, located some hundred meters from the dolmen, in underlying formations, of the Lower and Middle Cenomanian. This conclusion confirms L. A. Castro work.

3. Intentionality is visible not only in the incorporation of these blocks into the monuments in question, but also in the way they were arranged in the architecture. There is evidence that symmetry and other aesthetic criteria were used, 
which may be explained by the scenic effect produced by the surfaces of the slabs inside the tombs when illuminated by torchlight. Thus, in Monte Abraão, the visual effect results from the alternation between smooth and 'decorated' surfaces, while in Estria (considered the most recent of the three tombs) all the slab surfaces bearing ichnofossils face inwards into the interior of the monument, which would have intensified the sensation required.

In Portugal, petrography studies focusing on the selection and arrangement of materials in megalithic structures are still limited. The dolmens of Vale de Rodrigo contained slabs that came from various kilometers away (porphyroid rocks with large feldspar phenocrystals) although there is no evidence of any pattern in the way they have been arranged. In contrast, the dolmen of Rabuje 4 shows intentionality in the layout of the different petrography types in the monument, a situation which, though not unique, opens up interesting perspectives for the development of this line of research in Portugal.

4. Finally, the two anthropomorphic figures depicted on the outer side of one of the slabs at Pedra do Mouros (the megalith in the worst state of conservation, despite being the largest of the three) were subjected to a comparative study, also carried out for the first time. This led to the conclusion that they may have been executed at any time from the period when the monument was first built until the Iron Age. The first possibility would have meant that this large megalith (of almost 5 meters in height) would never have had a complete mound. If so, it would not be unique in the region, as in Monte Abraão, no unequivocal evidence of a mound has yet been found.

\section{ACKNOWLEDGMENTS}

Karen Benett for the translation into English of the original in Portuguese and Maia Langley for the revision of the abstract.

\section{BIBLIOGRAPHY}

Almagro Basch, M. 1966: Las estelas decoradas del suroeste peninsular. Bibliotheca Praehistorica Hispana VIII, CSIC. Madrid.

Almagro-Gorbea, M. 1993: "Les steles anthropomorphes de la Péninsule Ibérique". In Les représenta- tions humaines du Néolithique à l'Âge du Fer. 115 Congrès National des Sociétés Savantes, Pré et Protohistoire (Avignon, 1990): 123-139. Paris.

Almeida, F. M. (coord.) 1991: Carta Geológica de Portugal, Folha 34-A, Sintra. Serviços Geológicos de Portugal: Lisbon.

Anati, E. 1980: Valcamonica: 10.000 anni di storia. Centro Camuno di Studi Preistorici. Brescia.

Barbosa, I. V. 1863: "Fragmentos de um roteiro de Lisboa (Inédito): Arrabaldes de Lisboa". Archivo Pittoresco 6: 185-186 and 192.

Barbosa, I. V. 1868: "Os monumentos prehistoricos: Dolmin ou anta de Adrenunes, na serra de Cintra". Archivo Pittoresco 11: 377-379.

Batata, C. and Gaspar, F. 2009: Carta arqueológica do concelho de Pampilhosa da Serra. Câmara Municipal de Pampilhosa da Serra/OZECARUS, Serviços Arqueológicos, Lda. Torres Novas.

Beltrán, A. 1989: "Perduración en el arte prehistórico del 'estilo Paleolítico' durante el Mesolítico y los posibles enlaces el 'levantino'. Coloquio Internacional del Arte Prehistórico" (Montemor-o-Novo, 1987). Almansor 7: 125-166.

Benoliel, J. 1907: "[Photo] Romaria do Senhor da Serra, a Pedra Alta na Quinta do Marquês. Ilustração Portuguesa September 2: 314. AFlimg23\A11085. jpg. Online http://arquivomunicipal.cm-lisboa.pt

Bettencourt, A. M. S.; Sanches, M. J.; Dinis, A. and Cruz, C. S. 2004: "The rock engravings of Penedo do Matrimónio,in Campo de Caparinho, Vilar de Perdizes, Montalegre (Northern Portugal)". Journal of Iberian Archaeology 6: 61-82.

Boaventura, R. 1999-2000: "A proveniência geológica das antas de Rabuje (Monforte, Alentejo)". Ibn Maruan 9-10: 303-310.

Boaventura, R. 2000: "A geologia das antas de Rabuje (Monforte, Alentejo)". Revista Portuguesa de Arqueologia 3 (2): 15-23.

Boaventura, R. 2009: As antas e o Megalitismo da região de Lisboa. PhD in Prehistory. School of Humanities of the University of Lisbon. Lisbon. http://repositorio.ul.pt/handle.net/10451/587 (accessed 31-X-2011).

Breuil, H. 1933: Les peintures rupestres schématiques de la Péninsule Ibérique. I - au Nord du Tage. Imprimerie de Lagny. Lagny.

Bueno Ramírez, P. and Balbín-Behrmann, R. de 1992: "L'art mégalithique dans la Péninsule Ibérique. Une vue d'ensemble". L'Anthropologie 96 (2-3): 499572.

Bueno Ramírez, P. and Balbín-Behrmann, R. de 2003: "Arte megalítico versus megalitismo: origen del sistema decorativo megalítico". In V. S. Gonçalves (coord.): Muitas antas, pouca gente? Actas do 1. ${ }^{\circ}$ Colóquio Internacional sobre Megalitismo (Reguengos de Monsaraz 1996): 283-302. Lisbon. 
Bueno Ramírez, P.; Balbín-Behrmann, R. de and Barroso Bermejo, R. 2007: “Chronologie de l'art Mégalithique ibérique: ${ }^{14} \mathrm{C}$ et les contextes archaéologiques". L'Anthropologie 111: 590-654.

Bueno Ramírez, P.; Balbín-Behrmann, R. de and Barroso Bermejo, R. 2009a "Constructores de megalitos y marcadores gráficos. Diacronías y sincronías en el Atlántico Ibérico". In P. Bueno Ramírez, R. de Balbín-Behrmann, R. González Antón and C. del Arco Aguilar (eds.): Grabados rupestres de la fachada atlântica europea y África. British Archaeological Reports, International series 2043, Archaeopress. Oxford: 149-172.

Bueno Ramírez, P.; Balbín-Behrmann, R. de and Barroso Bermejo, R. 2009b: "Pintura megalítica en Andalucía". In R. Cruz-Auñon Briones and E. Ferrer Albelda (coords.): Estudios de Prehistoria y Arqueología en Homenaje a Pilar Acosta Martínez. Universidad de Sevilla. Sevilla: 141-170.

Cabré, J. 1916: Arte rupestre gallego y portugés (Eira d'os Mouros y Cachão da Rapa). Livraria Férin. Lisbon.

Cardoso, J. L. 1992: “A Lapa do Bugio”. Setúbal Arqueológica 9-10: 89-225.

Cardoso, J. L. 2008: "Correspondência seleccionada enviada a O. V. Ferreira: Cinquenta anos de actividade arqueológica (1946-1995)". Estudos Arqueológicos de Oeiras 16: 383-408.

Casa, J.; Vargas, J. M. and Oliveira, R. 1998: “As antas de Belas na tradição e no imaginário popular”. In Olho Vivo. Associaçâo para a Defesa do Património Ambiente e Direitos Humanos. Antas de Belas: Um património a preservar. Queluz: 27-29.

Castro, L. A. 1961: "Um novo aspecto interpretativo da ornamentação dos monumentos megalíticos". Revista de Guimarães 71: 255-260.

Correia, V. 1917: “Notas: Gravuras do 'dolmen' da Pedra dos Mouros (Belas)". Terra Portuguesa 12: 185-186.

Correia, V. 1921: El Neolítico de Pavia (AlentejoPortugal). Memorias de la Comisión de Investigaciones Paleontológicas y Prehistóricas 27, Junta para la Ampliación de Estudios e Investigaciones Científicas, Museo Nacional de Ciencias Naturales. Madrid.

Cunha, A. L. and Cardoso, J. L. 2002-2003: “A anta do Penedo Gordo (Belver, Gavião)". Estudos PréHistóricos 10-11: 31-53.

Ferreira, O. V. 1959: "Inventário dos monumentos megalíticos dos arredores de Lisboa". In Actas e Memórias do $1 .^{\circ}$ Congresso Nacional de Arqueologia (Lisboa, 1958) 1: 215-233. Lisbon.

Ferreira, O. V. 1963: "Notícia de algumas estações pré-históricas e objectos isolados inéditos ou pouco conhecidos". Boletim da Junta Distrital de Lisboa. $2^{\text {nd }}$ series: $59-60$.
Fontes, J. 1932: "Sobre algumas figuras rupestres do sanctuario pré-historico do Gião". Revista de Arqueologia 1: 75-82.

Gomes, M. V. 2004-2005: “A hierogamia do Penedo do Matrimónio (Montalegre, Vila Real)". Arqueologia e História 56-57: 51-63.

Gomes, M. V.; Monteiro, P. 1976-1977: “As estelas decoradas da Herdade de Pomar (Ervidel-Beja). Estudo comparado". Setúbal Arqueológica 2-3: 281-343.

Gonçalves, V. S. 1999: Reguengos de Monsaraz: Territórios megalíticos. Câmara Municipal de Reguengos de Monsaraz. Lisbon.

Hoskin, M. 2001: Tombs, Temples and Their Orientations: A New Perspective on Mediterranean Prehistory. Ocarina Books. Oxford.

Kalb, P. 1996: "Megalith-Building, Stone Transport and Territorial Markers: Evidence from Vale de Rodrigo, Évora, South Portugal". Antiquity 70 (269): 683-685.

Kalb, P.; Höck, M. 1995: "Investigação Geológica na Zona Megalítica de Vale de Rodrigo, Évora”. Proceedings 3. ${ }^{a}$ Reunião do Quaternário Ibérico (Coimbra 1993): 469-474. Coimbra.

Leisner, V. 1965: Die Megalithgräber der Iberischen Halbinsel. Der Westen. Walter de Gruyter. Berlin. vol. 3.

Marques, T. and Ferreira, C. J. 1987: "Antas de Belas”. Informação Arqueológica 8: 52-53.

Marques, T.; Lourenço, F. and Ferreira, C. J. 1991: "Antas de Belas: Uma tentativa de valorização do património arqueológico nos arredores de Lisboa". Actas das IV Jornadas Arqueológicas (Lisboa, 1990): 87-91. Lisbon.

Martí Oliver, B. y Hernández Pérez, M. 1988: El Neolithic valencià: arte rupestre e cultura material. Servicio de Investigación Prehistórica. València.

Ramalho, M. M.; Pais, J.; Rey, J.; Berthou, P. Y.; Alves, C. A. M.; Palácios, T.; Leal, N. and Kullberg, M. C. 1993: Carta geológica de Portugal na escala de 1/50.000 - 34-A: Notícia explicativa da folha 34-A Sintra. Serviços Geológicos de Portugal. Lisbon.

Ribeiro, C. 1880: Estudos Prehistoricos em Portugal: Noticia de algumas estações e monumentos prehistoricos. II - Monumentos megalithicos das visinhanças de Bellas. Typographia da Academia. Lisbon.

Scarre, C. 2004: 'Monumentos de Pedra 'Rude' e Pedras Troféu: a relação com os materiais nos megálitos da Europa ocidental". In M. Calado (coord.): Sinais de Pedra. $1{ }^{\circ}$ Colóquio Internacional sobre Megalitismo e Arte Rupestre (Évora 2003): Évora. http://www.crookscape.org/textset2007/text13.html (accessed 31-X-2011).

Silva, E. J. L. 1993: "Représentations humaines sur deux monuments mégalithiques de la région nord du Portugal". In Les représentations humaines $d u$ Néolithique à l'Âge du Fer. 115 Congrès National des Sociétés Savantes, Pré et Protohistoire (Avignon 1990): 21-27. Paris. 
Simões, A. F. 1878: Introducção á Archaeologia da Península Ibérica: Parte Primeira, Antiguidades Prehistoricas. Livraria Ferreira. Lisboa.

Sousa, E. M. 1990: "Núcleo de gravuras proto-históricas descoberto a N. do Cabo da Roca"; breve noticia. Zephyrus 43: 363-369.
Zbyszewski, G.; Ferreira, O. da V.; Leitão, M. and North, C. T. 1977: "Descoberta de insculturas com a figura humana estilizadana região de Brotas (Mora). O Penedo de Almoinha". Comunicações dos Serviços Geológicos de Portugal 61: 33-41. 